\title{
THE STRUCTURAL CHECK OF HIGH RISE BUILDING DESIGN
}

\author{
W. P. Edwards*
}

Some years ago a paper describing the operations of the High-Rise Building Committee of Japan was presented to both Auckland and Wellington Branches of the Earthquake Group of the Consultants' Division. Subsequently, the Group referred the paper to the N.Z. National Committee on Earthquake Engineering and to the N.Z . Society for Earthquake Engineering with a recommendation that these bodies take the initiative in setting up a similar high-rise building committee in New Zeal and.

The National Committee and the Society agreed in principle with the recommendation and formed a joint Sub-Committee to report on the question.

This Sub-Committee consists of six members, three residing in Wellington, two in Auckland and one in Dunedin. One fully attended meeting was held in Wellington and, thereafter, meetings were held by the Wellington members and further work carried out by correspondence.

The Sub-Committee defined the scope of a High-Rise Building Committee as follows :-

To examine the structural designs of buildings higher than ten storeys (excluding penthouses) or higher than 120 feet to uppermost concrete floor and to report on the ability of such structures to resist earthquakes and wind forces; and to examine buildings of lesser height which, because of unusual features, have been referred to the Committee.

In elaboration of this definition, it could be added'that the purpose of the HighRise Building Committee in examining building designs will be to ensure that the philosophy employed in overall design and detailing is such as to guarantee integrity of performance of the completed building. One of the objectives would be to minimise panic amongst, or injury and loss of 1 ife to, persons in and around buildings during earthquakes.

In the opinion of the Sub-Committee, membership of the High-Rise Building Committee should consist of senior engineers (structural design) of the Ministry of Works, Local Authorities, D.S.I.R., Building Research and Consulting Engineers, the actual representation suggested being as follows :-

\footnotetext{
* Partner, Edwards, Clendon and Partners, Wellington.
}

\author{
M.O.W. (Structural Design) \\ Local Authorities \\ Universities, D.S.I.R. and \\ Building Research \\ Consulting Engineers

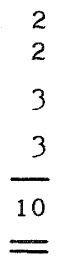

In addition, the Committee itself should have the right to appoint a further two members, if so desired. The High-Rise Building Committee would be a working committee and the composition of its membership (expected to deal with 25 projects per yearl should not be influenced by non-technical considerations. The members, then, should :-

a. Have a high degree of expertise in the design and construction of high rise buildings, or

b. Be actively engaged in advanced research in the field of earthquake engineering, and

c. Have sufficient time at their disposal either personaliy or through expert staff under their control to deal expeditiously with the tasks involved.

Provided that members with the requisite qualifications are available, it is felt that a limit should be placed on the period of service as a member of the High-Rise Building Committee. The present thinking is that members could serve for a maximum period of two years, with half the committee retiring each year. This would allow new members to be appointed but would still maintain some measures of continuity of policy.

Meetings of the full committee would be held once a month in wellington. Meetings of sub-committees dealing with particular projects would be held more frequently, and the Committee would have power to co-opt especially qualified persons for this purpose.

It has been recommended that, initially, the service of committee members be on a voluntary basis, travelling expenses only being paid. At this stage, then, it is envisaged that the charge for the services provided by the High-Rise Building Committee would be nominal.

In regard to the actual introduction of such a Committee, it is considered that there are two possible methods by which this could be achieved. The first by the introduction of appropriate legislation, but this would necessarily involve inevitable delays; and the second method, which is favoured, is that of 
obtaining the co-operation of the Municipal and Counties Associations. If these bodies approve the setting up of a High-Rise Building Committee then it would be possible to produce a special code of practice suitable for adoption by them. The code of practice would be submitted to the standards Association as a draft specification for circulation and comment and would finally be produced as a S.A.N.Z. publication.

Approaches have been made to the Municipal and Local Bodies Divisions of the N.Z.I.E. and to the N.Z. Institute of

County Engineers. The latter two organisations have announced agreement in principle with the submissions made, but the Municipal Division (who will be most directly concerned) have the matter under consideration. Members of the society will be kept informed of further progress.

In conclusion, it is pertinent to mention that as a direct result of the San Fernando Quake 1971, SEAOC have included in their "Report of the Ad Hoc Committee on Direction Study - Seismic. October, $1971^{\prime \prime}$ the following statement :-

\section{" SPECIAL ADVISORY BOARD}

The Committee recommends that a special Advisory Board be set up in the code to establish the design criteria for all important structures, structures that are dynamically unsymmetrical, or structures on difficult sites. It would be difficult to write a code to cover all such factors." 